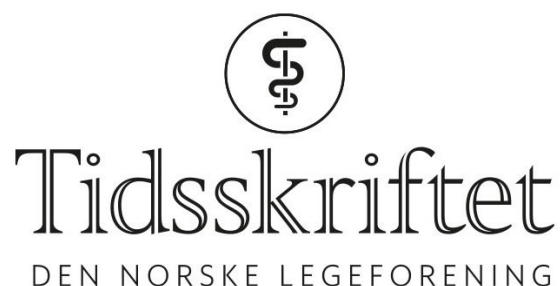

\title{
Rettelse: Er helserisikoen ved snus undervurdert?
}

RETTELSE

GUNN ELISABETH VIST

TOM KRISTIAN GRIMSRUD

HÅKON VALEN

RUNE BECHER

BENDIK CHRISTIAN BRINCHMANN

IDA-KRISTIN ØRJASAETER ELVSAAS

JAN ALEXANDER

Tidsskr Nor Legeforen 2020; 140. doi:10.4045/tidsskr.19.0746.

I Tabell 1 ved Parkinsons sykdom skal det stå: HR o,38 (o,23-0,63).

Vi beklager feilen, den er rettet på nett.

Publisert: 24. juni 2020. Tidsskr Nor Legeforen. DOI:10.4045/tidsskr.20.0516

(C) Tidsskrift for Den norske legeforening 2020. Lastet ned fra tidsskriftet.no 